\title{
Sheep Production and Breeding Systems in North Western Lowlands of Amhara Region, Ethiopia: Implication for Conservation and Improvement of Gumz Sheep Breed
}

\author{
Yohannes Dagnew¹, Mengistu Urge², Yosef Tadesse ${ }^{2}$, Solomon Gizaw ${ }^{3}$ \\ ${ }^{1}$ Department of Animal Science, Bule Hora University, Bule Hora, Ethiopia \\ ${ }^{2}$ School of Animal and Range Science, Haramaya University, Dire Dawa, Ethiopia \\ ${ }^{3}$ International Livestock Research Institute, Addis Ababa, Ethiopia \\ Email:yohanesdagnew@yahoo.com
}

How to cite this paper: Dagnew, Y., Urge, M., Tadesse, Y. and Gizaw, S. (2017) Sheep Production and Breeding Systems in North Western Lowlands of Amhara Region, Ethiopia: Implication for Conservation and Improvement of Gumz Sheep Breed. Open Journal of Animal Sciences, 7, 179-197. https://doi.org/10.4236/ojas.2017.72015

Received: March 12, 2017

Accepted: April 22, 2017

Published: April 28, 2017

Copyright $(9) 2017$ by authors and Scientific Research Publishing Inc. This work is licensed under the Creative Commons Attribution International License (CC BY 4.0).

http://creativecommons.org/licenses/by/4.0/

(c) †) Open Access

\begin{abstract}
A questionnaire survey and focused group discussions were conducted to characterize sheep production systems and traditional breeding practices of Gumz sheep as an essential step for designing the Gumz sheep breed conservation and improvement programme. A total of 240 households were included in the study during the period of November 2016 to March 2016. Smallholder farmers kept sheep as a source of income, meat and wealth with an index value of $0.43,0.19$ and 0.15 , respectively. Important purposes of large scale farmers for keeping sheep were source of cash income (0.57) and investment opportunity (0.22). Average sheep flock sizes were $17.25 \pm 0.68$ and $90.63 \pm 5.38$ at smallholder and large scale production systems, respectively. Smallholder sheep flocks' composition was $7.47 \pm 0.28 \mathrm{Gumz}, 3.68 \pm 0.25 \mathrm{Ru}-$ tana and $4.52 \pm 0.22$ Rutana-Gumz crossbred sheep. The corresponding figures for large scale farms were $21.2 \pm 1.4,30.7 \pm 1.69$ and $24.7 \pm 1.47$ sheep. The average numbers of rams in the smallholder sheep flocks were $0.31 \pm 0.04$ Gumz, $0.39 \pm 0.04$ Rutana and $0.24 \pm 0.03$ crossbreds, respectively. The corresponding figures for large scale farms were $3.10 \pm 0.13$ Rutana and $0.90 \pm$ 0.14 crossbreds. The Gumz sheep was large in number, but farmers prefer Rutana and its crosses than Gumz in both systems. Diseases, stock theft and labour shortage were reported as the main constraints of sheep production. Although the pure Gumz breed meets the multifaceted roles of sheep for the smallholder farmers, the Gumz sheep population was declining in number in the study area due to uncontrolled breeding with Rutana and high preference of farmers for crossbreds over Gumz sheep. It is observed that there is a risk of dilution and loss of genetic diversity of the Gumz sheep. Hence, we rec-
\end{abstract}


ommend designing of conservation-based breeding program to conserve the locally adapted Gumz breed as well as to improve sheep production and productivity in the area through rational utilization of all the three genotypes.

\section{Keywords}

Breeding Practices, Conservation, Gumz, Production System

\section{Introduction}

Ethiopia is endowed with diverse agro-ecological zones and corresponding large and diverse sheep resources numbering about 28.3 million heads [1]. Sheep are important sources of cash income and living banks to their owners [2] [3]. Sheep also play an important role in providing export commodities such as live animals and skins/leather to earn foreign currency [4]. Sheep account for $19 \%$ and $95 \%$ of the total livestock and small ruminant live animal export, respectively [5]. Ethiopia's lowland sheep and goat breeds are in high demand in neighboring and Middle East countries. Lowland breeds are more preferred than highland breeds by exporters [6]. The performance of the sheep industry has been poor compared with other African countries due to inadequate feed and nutrition, widespread disease and health problem, poor management and marketing system [7] [8]. The current sheep production may not be meeting the increasing domestic demand due to increased human population and urbanization [9]. There is also increasing demand for sheep and sheep products in the neighbouring countries like Sudan and North African countries, which is an opportunity for producers. Northwestern lowland of Amhara region is among the high potential areas for livestock production and for the supply of live animals to the Sudan market [10] and used either for local consumption or for re-exporting to Egypt, Libya and Yemen. The major sheep breeds kept in this area are Gumz, Rutana and their crossbred. The local Gumz sheep are prolific, adaptable to the hot environmental condition of the area and known for their tasty meat [11]. However, farmers in the study areas are reported to be more interested in the Rutana and their crossbred with Gumz sheep which are more preferred than the indigenous Gumz breed in the export market. High human population growth and improvement of living standard increase the demand for animal protein, which consequently leads to bulk supply of the best animals and crossing with exotic breeds to meet the demand for large number and best animals in the market. This is seriously threatening the existence of indigenous populations. Hence, the current drive for rapid livestock development through crossbreeding and the threat status of indigenous sheep [12] requires research to design and implement suitable breeding strategies so as to improve productivity and conserve indigenous breeds. Absence of adequate baseline information about the production system is considered as one of the bottlenecks for development of strategy for breed improvement and conservation in most developing countries. 
[13] also underlined the need for comprehensive description of the production system in order to understand the special adaptative character of breeds and designing of breeding programmes. Thus, characterization of production system, breeding practices and major production constraints help to ensure sustainable use and development of sheep genetic resource. This information is also useful for policy makers and extension services to plan improvement and conservation strategies for the sheep breed. This study was therefore undertaken to generate information on the sheep breeds and breeding systems, to characterize the production system, to describe the production objectives and breeding practices of the sheep keepers, to provide baseline information for designing conservation-based breeding programs for Gumz sheep and rational utilization of the Rutana sheep genetic resource.

\section{Materials and Methods}

\subsection{Study Areas}

The study was conducted in the lowlands of north western Ethiopia, Amhara region, along the Sudanese border, in Metema and Quara districts (Figure 1). Metema and Quara districts were selected for conducting the study due to accessibility and distribution of the sheep breeds studied purposively. In both of the

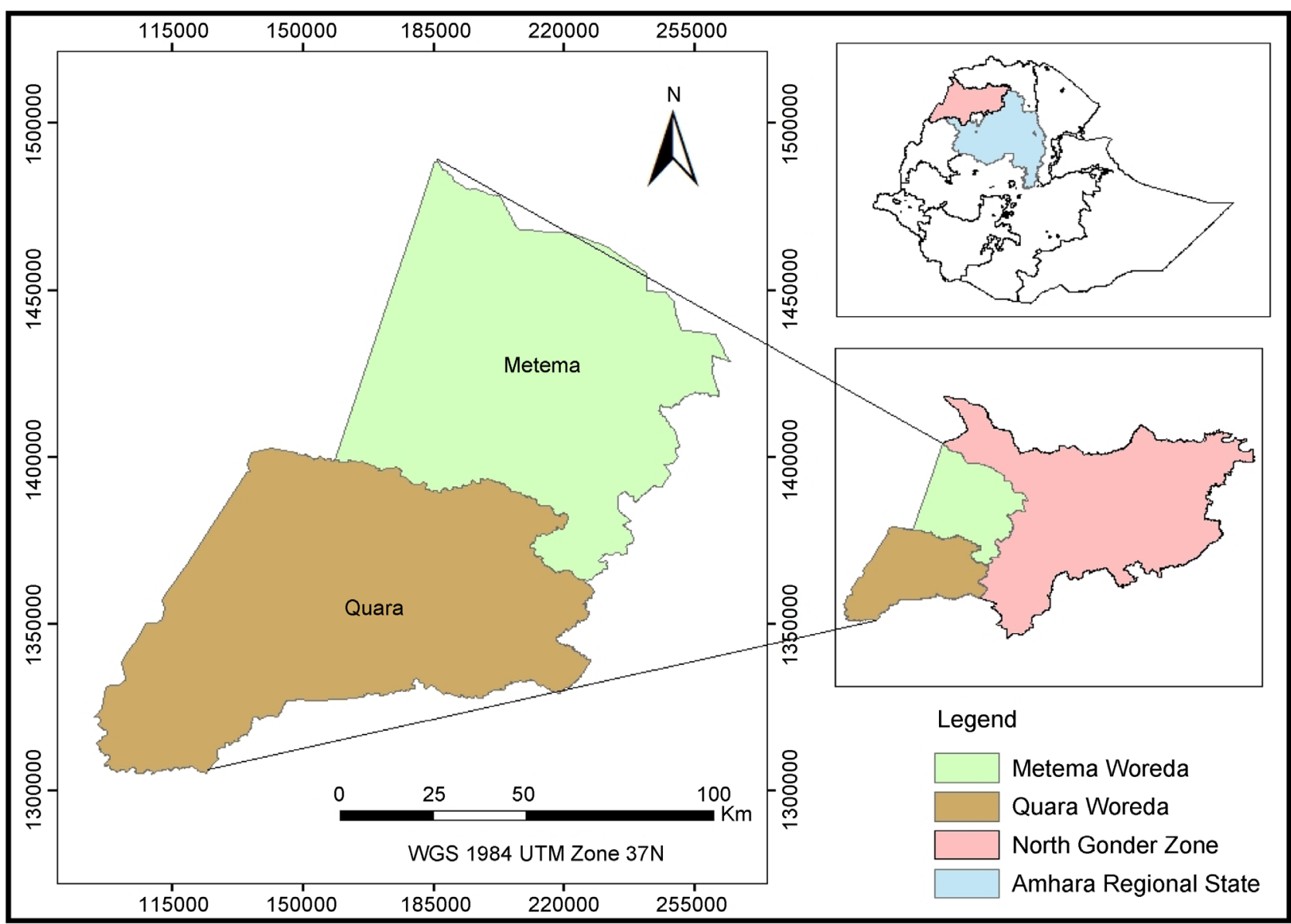

Figure 1. Map of study districts in North Gondar Zone of Amhara region. 
districts, agricultural production is characterized by a mixed crop-livestock production system. The major crops grown are sesame and cotton, which are the major export commodities of the country [14]. Metema is located between $12^{\circ} 40^{\prime} \mathrm{N}$ and $36^{\circ} 8^{\prime} \mathrm{E}$. It is situated at an altitude ranging from 500 to 1608 m.a.s.l. It has a uni-modal pattern of rainfall (June to September); with annual rainfall ranging from 850 to $1110 \mathrm{~mm}$ with a minimum and maximum average temperature of $22^{\circ} \mathrm{C}$ and $43^{\circ} \mathrm{C}$, respectively [11]. The production system of Metema district is characterized as a small scale and large scale mixed crop-livestock system. Sheep production is a common practice. Quara is located between $11^{\circ} 47^{\prime} \mathrm{N}$ and $12^{\circ} 21^{\prime} \mathrm{N}$ latitude and $35^{\circ} 16^{\prime} \mathrm{E}$ and $35^{\circ} 47^{\prime} \mathrm{E}$ longitude. The district is situated at an altitude ranging from 528 to 654 m.a.s.l. The annual rainfall range from $600 \mathrm{~mm}$ to $1200 \mathrm{~mm}$, and the average daily temperature is $31^{\circ} \mathrm{C}$ with $41.1^{\circ} \mathrm{C}$ and $19.2^{\circ} \mathrm{C}$ maximum and minimum temperature, respectively [15]. Sheep production in the area is practiced both by smallholder and large-scale farmers.

\subsection{Sampling Strategy and Data Collection Procedures}

In the north western lowlands, the study areas were classified into two production systems (smallholder and large scale crop-livestock production systems) based on sheep flock size, farmers sheep production practice, their breed preferences, level of input use and marketing systems. Multi-stage stratified sampling was employed to select Kebeles purposively based on sheep breed distribution, sheep population and accessibility. Three Kebeles were selected from each district representing smallholder production systems. Similarly, three investment sites were selected based on sheep breed distribution, sheep population and accessibility from each district representing large-scale production systems. Accordingly, a total of six kebeles (3 from each district) representing smallholder systems and six investments site (3 from each districts) representing large-scale production systems were selected. To calculate the total sample size, the following parameters were considered: $95 \%$ level of confidence (CL), 5\% desired level of precision and about $20 \%$ of the farmers kept both Gumz and Rutana sheep as confirmed by [11] in the study areas that are known for keeping Gumz sheep; thus, the sample size is determined using the single population proportion formula as described by [16]: Therefore, based on the above formula, the total sample size was 240 households. 180 of them would be sheep owners from smallholder production systems, and the rest 60 respondents from large scale production systems. A total of 240 households (30 from each kebele and 10 from each investment sites) were randomly sampled for the survey. Focus group discussions were held with development agents, key informants and elders before the commencement of the actual survey. These discussions were used to obtain information about the history of sheep breeds, population trends (declining, stable or increasing), farmers' reasons for keeping the various breeds and crossbreds, herding practice, grazing/communal land use, mobility and major sheep production constraints. A set of detailed structured questionnaire and check list were prepared and used to collect information from the 240 sheep owners of 
which 180 were farmers and 60 were large scale farmers in different sites by guided interviews. The questionnaire was prepared by ILRI (International Livestock Research Institute)-OADB (Oromiya Agricultural Development Bureau) for survey of livestock breeds in Oromiya and found to be effective for such studies [17] and adopted for the current research with some modification to fit in the study areas situation. This questionnaire was interpreted in local language to make it first understandable. The questionnaire was pre-tested to check clarity and appropriateness of the questions. Based on the questionnaire information on breeding systems, production objectives, flock structure, production constraints, feeding management, diseases prevalence and marketing system were gathered. Observational studies were also applied in the study areas in addition to historical information about the production system collected from direct questioning of the sheep owners. Primary and secondary data were the sources of information used for the study. Primary data sources were the key informants during guided interviews. The households were selected based on sheep possessions and willingness to be part of the survey. The method of data collection employed was a single-visit formal survey [18]. For group discussion, 10 sheep breeders with long experience in sheep rearing were selected from each districts and interviewed to gather reliable information on the history of sheep breeds, farmers' reasons for keeping the various breeds and major sheep production constraints. The questionnaire were designed to obtain information on general household characteristics, livestock and flock structure, flock management, breeding practices, disease prevalence, production objectives, feeding management and production constraints. Also information on the general composition of the flock, breed, age, sex, purpose of keeping sheep, way of herding and market systems were collected for this study.

\subsection{Data Analysis}

The data were analyzed using descriptive statistics (SPSS 20.0, 2008). Farmer's preference rankings were summarized into index as weighted averages. The indices were calculated as suggested by [19]; Index = Sum of (3 X number of household ranked first $+2 \mathrm{X}$ number of household ranked second $+1 \mathrm{X}$ number of household ranked third) given for an individual reason, criteria or preference divided by the sum of ( $3 \mathrm{X}$ number of household ranked first $+2 \mathrm{X}$ number of household ranked second $+1 \mathrm{X}$ number of household ranked third for overall reasons, criteria or preferences.

\section{Results and Discussion}

\subsection{Sheep Production Systems}

A good understanding of the production system under which indigenous sheep breed are raised is essential in planning suitable improvement and conservation programs for breeds [20] [21]. The existence of smallholder and large scale sheep production systems in the present study area is in accordance to the previous studies [14]. The smallholder production system is characterized by small-scale 
holding and traditional rain fed system, which mainly rely on family labor, cultivate 1 to 10 ha of land, grow sesame and cotton as cash crops and sorghum as food crop. Cattle, goat, sheep and donkey were the livestock species reared by smallholders. In large scale systems, cultivated land range from 50 to 600 ha. Farmers produced sesame, cotton and sorghum as cash crops. Large capital investment, predominantly mechanized rain fed system, larger livestock holding and substantial number of hired labor were some of the distinguishing characteristics of the large scale system. Cattle, sheep and goat are the main livestock species kept by large scale farmers. The characteristics of the two production systems should be considered in sheep development programs in the study areas. Moreover, a separate sheep breeding programs may be required to capture the advantage of the production systems.

\section{Land and Livestock holding}

Average land holding per farmer was 5.9 and 118 ha for smallholder and large scale farmers, respectively. According to [22] the smallholder holding is greater than the average landholdings of the highland districts of Debark (1.66 ha) and Layarmachiho (2.03 ha) districts. Only $8.6 \%$ and $11.5 \%$ of the land owned by smallholder and large scale farmers was used for grazing while most of the remaining land was used for growing crops. Out of the total crop land, about $65 \%$ and 35\% were used for cash crops and staple foods, respectively. The trend in land use was similar to the result reported by [14]. Grazing land has been decreasing due to an ever increasing human population and current greater use of communal grazing lands for crop production [14]. According to [23] the feed supply of the natural pasture in the Amhara National Regional State of Ethiopia is decreasing for similar reasons. Since the farmers were those having sheep, hundred percent of the respondents practiced sheep rearing (Table 1). Large scale farmers had the largest sheep flock sizes as compared to the smallholder farmers in both study districts. The smallholder sheep holding reported for Metema district is comparable to that reported by [11], which was $16.02 \pm 14.1$ sheep per household. The large flocks kept by the large scale farmers in the study area is due to viable cross border trade with Sudan and availability of uncultivable free grazing areas. The smallholder's sheep holding in the present study area is also larger than that in the highland regions of Ethiopia where land is in short

Table 1. Average livestock size per household (Mean \pm Standard error) in different production systems.

\begin{tabular}{ccccccc}
\hline & \multicolumn{5}{c}{ Production systems } & Over all \\
\cline { 2 - 7 } Livestock species & \multicolumn{2}{c}{ Smallholder } & \multicolumn{2}{c}{ Large-scale } & Small-holder & Large scale \\
\cline { 2 - 7 } & \multicolumn{2}{c}{ Metema (90)* } & Quara (90) & Metema (30) & Quara (30) & \\
Cattle & $16.24 \pm 1.77$ & $14.98 \pm 0.85$ & $43.28 \pm 5.43$ & $35.07 \pm 4.15$ & $15.61 \pm 0.98$ & $41.20 \pm 3.87$ \\
Sheep & $16.36 \pm 1.02$ & $18.14 \pm 0.91$ & $92.10 \pm 8.5$ & $85.76 \pm 5.48$ & $17.25 \pm 0.68$ & $90.63 \pm 5.38$ \\
Goat & $13.87 \pm 0.82$ & $14.56 \pm 0.77$ & $12.41 \pm 1.62$ & $14.41 \pm 0.99$ & $14.21 \pm 0.56$ & $13.53 \pm 0.92$ \\
Donkey & $1.47 \pm 0.07$ & $1.62 \pm 0.07$ & --- & --- & $1.54 \pm 0.05$ & --- \\
\hline
\end{tabular}

${ }^{\star}$ Numbers in brackets are number of respondents. 
supply due to human population pressure. The difference exist in animal holding should be considered in designing breeding programs in order to increase the chance of successful genetic improvement since flock size is a major determinant factor in designing effective genetic improvement. The dominance of sheep as compared to goat in the large scale production systems (Table 1) might be due to the high price and year round export market demand for sheep in Sudan and other Arabian countries. Dominance of goat and sheep over cattle in the smallholder production systems might be because of the fact that small ruminants are the major source of cash income, capital saving and food for smallholder farmers. The same trend was observed in Afar lowlands of Ethiopia where sheep and goat flock size was relatively higher than other livestock species [4] [24].

\section{Relative contribution of sheep farming}

Table 2 shows ranking of the contribution of sheep farming, other livestock enterprises and crop production for the family consumption and cash income. The smallholder systems give priority to crops as a source of food followed by cattle and goat. Whereas, for income generation cash crops contributed more than any other farming activities followed by sheep. In large scale systems, food crops ranked first as a means of food source followed by sheep and cattle. Large scale farmers ranked cash crops and sheep as first and second important source of income generation. This study showed that the smallholder and large scale farmers directly or indirectly depend on livestock mainly sheep as means of income generation and food source for the family. This use function of sheep should be taken into account during designing of breed improvement and conservation strategy. The contribution of sheep in the smallholder system was highly comparable to cash crops such as sesame, which are high value export commodities. The contribution of sheep production as a source of family income and food source (meat) recorded in the present study area is in agreement with reports from other parts of Ethiopian like Somali and West Gojjam [25]. The contribution of the off-farm employment (self and formal employment) also accounts for some portion of cash earned.

Table 2. Small scale and large scale farmers' ranking (index) of importance of major farming activities for the supply of food and income.

\begin{tabular}{ccccccc}
\hline \multirow{2}{*}{ Importance } & \multicolumn{3}{c}{ Food source } & \multicolumn{3}{c}{ Income source } \\
\cline { 2 - 7 } & Smallholder I & Large scale I & Overall I & Smallholder I & Large scale I & Overall I \\
\hline Food crop & 0.41 & 0.32 & 0.36 & 0.09 & 0.10 & 0.10 \\
Cash crop & 0.07 & 0.08 & 0.08 & 0.33 & 0.36 & 0.35 \\
Cattle & 0.21 & 0.21 & 0.21 & 0.12 & 0.14 & 0.13 \\
Sheep & 0.11 & 0.23 & 0.17 & 0.30 & 0.28 & 0.29 \\
Goat & 0.20 & 0.16 & 0.18 & 0.10 & 0.12 & 0.11 \\
Off farm & 0.0 & 0.0 & 0.0 & 0.06 & 0.0 & 0.03 \\
\hline
\end{tabular}

$\mathrm{I}=$ index; $\mathrm{I}=\operatorname{sum}$ of [ 3 for rank $1+2$ for rank $2+1$ for rank 3 ] given for an each farming activity divided by sum of [ 3 for rank $1+2$ for rank $2+1$ for rank 3 ] summed for all the farming activity. 


\section{Sheep production objectives}

Table 3 show the ranks of sheep production objectives by smallholder and large scale farmers. Results of earlier studies [20] indicated the knowledge of the reasons for keeping small ruminants is a prerequisite for setting operational breeding goals. The result of the present study show sheep to have multipurpose functions to support the livelihoods of smallholder farmers whereby their financial, source of food and wealth function ranked as paramount importance. However, intangible benefits of sheep, example, savings, insurance mainly against cop failure, socio-cultural and ceremonial purpose and prestige, were also considered important in the smallholder production system [2] [5] [19]. Similarly, tangible and intangible benefits of sheep, which show the multiple functions of indigenous local breeds in low input systems, were also reported in other studies [4] [7] [11] [26] [27]. Successful breeding program could be mainly achieved through including the intangible benefits (cultural, social and environmental) in the breeding objectives for sheep under smallholder production systems in the tropics. Therefore, considering the different socio-cultural perspective of the communities is important in the adoption of any breeding programme. The need to include intangible benefits in breeding goal definition for low-input production system has been discussed by [19]. This study noted higher economic value for litter size, lambing frequency and 12 month live weight to be important when intangible returns were included in the breeding objectives in smallholder production systems. In large scale systems, the primary reason of keeping sheep was income generation and investment opportunities indicating demand driven production objectives. The variation in production objectives between production systems observed in the current study are likely to be related to differences in social and economic contexts. In spite of all the multifaceted advantages of Gumz sheep mentioned by smallholder farmers, this study showed declining flock sizes in Gumz sheep, which implies the need for breeding strategies that target genetic improvement and conservation of the breed.

Table 3. Purpose of keeping sheep and the ranking of the importance of these purposes by production system.

\begin{tabular}{|c|c|c|c|c|c|c|c|c|c|}
\hline \multirow{3}{*}{ Purposes } & \multicolumn{8}{|c|}{ Production systems } & \multirow{3}{*}{$\begin{array}{c}\text { Overall } \\
\text { I }\end{array}$} \\
\hline & \multicolumn{4}{|c|}{ Smallholder } & \multicolumn{4}{|c|}{ large scale systems } & \\
\hline & 1 & 2 & 3 & I & 1 & 2 & 3 & I & \\
\hline Income & 81.7 & 6.7 & 1.7 & 0.43 & 83.3 & 25.0 & 41.7 & 0.57 & 0.50 \\
\hline Consumption & 6.1 & 35 & 28 & 0.19 & 0.0 & 10.0 & 0.0 & 0.04 & 0.12 \\
\hline Saving & 2.8 & 28.3 & 23.3 & 0.14 & 0.0 & 18.3 & 15.0 & 0.09 & 0.11 \\
\hline Wealthy & 9.4 & 25.6 & 31.7 & 0.15 & 0.0 & 15.0 & 20.0 & 0.08 & 0.12 \\
\hline Investment & 0.0 & 0.0 & 0.0 & 0.0 & 6.7 & 31.7 & 23.3 & 0.22 & 0.11 \\
\hline Insurance & 0.0 & 4.4 & 40.6 & 0.08 & 0.0 & 0.0 & 0.0 & 0.0 & 0.04 \\
\hline
\end{tabular}

$\mathrm{I}=$ index; $\mathrm{I}=$ sum of [ 3 for rank $1+2$ for rank $2+1$ for rank 3 ] given for an individual purpose divided by sum of [ 3 for rank $1+2$ for rank $2+1$ for rank 3 ] summed for all the purpose. 


\subsection{Sheep Breeding Systems}

The breeding systems practiced in the study area were both pure-breeding and crossbreeding. The most important sheep breeds found in the study areas were the indigenous Gumz and the exotic Rutana and few highland breeds. In addition, there is a crossbred sheep between Gumz and Rutana. Farmers reported that they managed to keep purebred Gumz for pure breeding and still practice crossbreeding between Gumz and Rutana breed. The proportion of the three genotypes (Gumz, Rutata and crossbreds) varies across the two production systems. The smallholder farmers primarily keep the indigenous Gumz sheep followed by the crossbreds (Table 4). Whereas, the most represented sheep breed in the large scale production systems was the introduced Rutana sheep followed by the crossbreds. The average sheep flock size reported for smallholder system in the present study was higher than that reported at different districts by [11] and [28] for Gumz (16.02) and Horro (11.3), respectively. Larger flock size (24.0 to 19.0 /heads per household) than in the present study was also reported by [29] and [30] in the central highland and lowlands of Ethiopia. Variation in flock sizes of sheep and goats among the production system across Ethiopia was also confirmed by the study of [12]. This variation is attributed to factors such as role of livestock, availability of land and feed and reliability of crop production. Hence, the suitability and availability of uncultivable large extensive grazing land for sheep production and year round demand of sheep at Sudan market could have contributed to owning of larger sheep flock size.

The higher smallholder flock size is advantages for designing village-based breeding programs. Also larger flocks in commercial production are suitable to introduce selective breeding within each farm. There was a difference in proportion among breeds and sexes in the sheep flocks. Both smallholders and commercial farmers owned higher number of Gumz ewes and ewe lambs than ram lambs and rams. This results in a larger number of lambs, which can speed up the effectiveness of selective breeding because of the high selection intensity. The

Table 4. Mean of sheep composition by age and sex group per household in the two production system.

\begin{tabular}{|c|c|c|c|c|c|c|c|c|c|c|c|c|c|}
\hline \multirow[b]{3}{*}{ Age } & \multirow[b]{3}{*}{ Sex } & \multicolumn{6}{|c|}{ Smallholders systems } & \multicolumn{6}{|c|}{ Large scales systems } \\
\hline & & \multicolumn{2}{|c|}{ Gumz } & \multicolumn{2}{|c|}{ Rutana } & \multicolumn{2}{|c|}{ Crossbred } & \multicolumn{2}{|c|}{ Gumz } & \multicolumn{2}{|c|}{ Rutana } & \multicolumn{2}{|c|}{ Crossbred } \\
\hline & & Mean & $\mathrm{SE}$ & Mean & $\mathrm{SE}$ & Mean & $\mathrm{SE}$ & Mean & $\mathrm{SE}$ & Mean & $\mathrm{SE}$ & Mean & SE \\
\hline \multirow[t]{2}{*}{$0-6$} & $\mathrm{~F}$ & 0.70 & 0.06 & 0.57 & 0.07 & 0.81 & 0.06 & - & - & 3.38 & 0.31 & 5.60 & 0.35 \\
\hline & M & 1.17 & 0.09 & 0.61 & 0.08 & 1.04 & 0.08 & - & - & 4.02 & 0.43 & 6.40 & 0.58 \\
\hline \multirow[t]{2}{*}{$6-12$} & $\mathrm{~F}$ & 1.30 & 0.09 & 0.66 & 0.07 & 0.95 & 0.07 & - & - & 3.73 & 0.30 & 3.82 & 0.27 \\
\hline & $\mathrm{M}$ & 0.87 & 0.07 & 0.61 & 0.07 & 0.87 & 0.06 & - & - & 4.17 & 0.48 & 4.80 & 0.38 \\
\hline \multirow[t]{2}{*}{$>12$} & $\mathrm{~F}$ & 3.00 & 0.13 & 0.88 & 0.06 & 0.62 & 0.07 & 21.2 & 1.4 & 12.3 & 0.69 & 3.22 & 0.53 \\
\hline & $\mathrm{M}$ & 0.31 & 0.04 & 0.39 & 0.04 & 0.24 & 0.03 & - & - & 3.10 & 0.13 & 0.90 & 0.14 \\
\hline \multicolumn{2}{|c|}{ Overall means } & 7.47 & 0.28 & 3.68 & 0.25 & 4.52 & 0.22 & 21.2 & 1.4 & 30.6 & 1.69 & 24.7 & 1.47 \\
\hline
\end{tabular}

$\mathrm{SE}=$ Standard Error; $\mathrm{M}=$ Male; $\mathrm{F}=$ Female 
highest proportion of breeding ewes in the current study was similar to that reported in earlier studies [20] [25] indicating the practice of retaining ewes for breeding purposes and as a manifestation of wealth and prestige. The removal of males for sale is another possible factor contributing to the high proportion of ewes per flock. Since the main purpose of sheep production in the study area is for cash income and home consumption, male animals are either sold or slaughtered and their number remains small in the flock. Large scale farmers do not keep Gumz rams rather they use Rutana as sire breed to produce crossbreed. The small size and lower carcass weight of Gumz as compared to Rutana and crossbred sheep is the reason of the practice. As a result large scale farmers do not have the willingness to get involved in pure Gumz sheep rearing. This practice may reduce the population of the Gumz sheep breed and require better breeding strategy to conserve indigenous Gumz breed. The large scale farmers also keep small number of crossbred rams with the purpose of maintaining pure Rutana female, which may lead to reduced Gumz blood level of the next generation of lambs with a consequence of dilution and long term replacement of the Gumz with Rutana sheep breed.

\section{Herding Practices}

Herding practice have an implication for designing genetic improvement programs and introducing improved sheep management such as strategic health interventions at village level [31]. The flock herding practices of the smallholder and large scale farmers reflects the breeding managements and has an impact on the flock size. The major type of herding practiced in the study areas was free grazing. About $51 \%, 31.7 \%$ and $17.2 \%$ of the smallholder farmers herd sheep together with goat, separate and either separate or sometimes with goat depending on the availability of hired labor, respectively. Because of their feeding habit, farmers prefer to manage sheep separately, but the majority of the smallholder farmers keep sheep with other livestock because of the shortage of labor [4] [24] reported that sheep and goat are herded together in Afar pastoral and agro pastoral system. In the contrary about $62 \%$ of the large scale farmers herd sheep separately and 38\% rear sheep and goat flock together. According to [29], sheep in the central highlands of Ethiopia are herded separately for grazing all year round using family members. (Table 5 )

\subsection{Constraints to Sheep Production}

Major constraints associated with sheep production as ranked by respondents are presented in Table 6. Diseases, labor shortage, stock theft, drought, predator

Table 5. Herding practices across production systems in the study areas.

\begin{tabular}{ccc}
\hline & \multicolumn{2}{c}{ Production System } \\
\hline Sheep herding & Smallholder systems $(\%)(\mathrm{n}=180)$ & Large Scale systems $(\%)(\mathrm{n}=60)$ \\
\hline Herded separately & 31.7 & 61.7 \\
Herded with goat & 51.1 & 38.3 \\
Separately or together with goat & 17.2 & --
\end{tabular}


Table 6. Sheep production constraints ranked by respondents and priority indices in different production systems.

\begin{tabular}{|c|c|c|c|c|c|c|c|c|c|}
\hline \multirow{3}{*}{ Constraints } & \multicolumn{8}{|c|}{ Production systems } & \multirow{3}{*}{ Overall } \\
\hline & \multicolumn{4}{|c|}{ Smallholders } & \multicolumn{4}{|c|}{ Large scales } & \\
\hline & 1 & 2 & 3 & I & 1 & 2 & 3 & I & \\
\hline Diseases & 54.4 & 35.0 & 20.0 & 0.42 & 43.3 & 31.7 & 25.0 & 0.36 & 0.39 \\
\hline Feed shortage & 8.3 & 6.7 & 8.3 & 0.08 & 5.0 & 11.7 & 10.0 & 0.08 & 0.08 \\
\hline Labour shortage & 13.3 & 20.6 & 31.7 & 0.19 & 21.7 & 20.0 & 20.0 & 0.21 & 0.20 \\
\hline Theft & 17.2 & 30.0 & 25.6 & 0.23 & 18.3 & 15.0 & 21.7 & 0.18 & 0.21 \\
\hline Predator & 6.7 & 7.8 & 13.9 & 0.08 & 8.3 & 13.3 & 10.0 & 0.10 & 0.09 \\
\hline Conflict & 0.0 & 0.0 & 0.5 & 0.0 & 3.3 & 8.3 & 13.3 & 0.07 & 0.04 \\
\hline
\end{tabular}

$\mathrm{I}=$ index; $\mathrm{I}=\operatorname{sum}$ of [ 3 for rank $1+2$ for rank $2+1$ for rank 3 ] given for an individual constraint divided by sum of [ 3 for rank $1+2$ for rank $2+1$ for rank 3 ] summed for all the constraints.

and conflict between farmers were identified as the most important constraints limiting sheep production (Table 6). This is in agreement with that reported by [5] in Southern Region of Ethiopia. Disease and parasite were the most important constraints hindering sheep production by causing high mortalities. Similar to the present study, [32] attributed the decline in livestock population in northern Ethiopia to the high disease and parasite prevalence and shortage of feed. Labour shortage as a major constraint to sheep production was also reported in different parts of Ethiopia [7] [24]. The high theft incidences reported in the study area was ascribed to proximity of the districts to Sudan making it easier for sheep rustlers to trek the animals across the border. The marketing channels of stock, which involve towns and its surrounding townships where there is a ready market for the mutton meat and made it easier to trade the stolen stocks [33]. To reduce sheep thefts, law enforcement agents should augment farmers' efforts by carrying out regular day and night patrols in the village. Formation of neighborhood watch committees to patrol the villages during the evening can also help to reduce the risk [34]. Feed shortage especially in the long dry season was critical problem in both production systems. Predator and conflict were minor concerns in both systems of sheep production.

\section{Feed resources}

In the wet season, natural pasture grazing on communal and private land was the major sources of feed for sheep in both production systems (Table 7). Dry seasons feed resource comprises natural pasture, trees and shrubs, stubble grazing and crop residues with variable magnitude of uses of the feed types between the two seasons. Higher private natural pasture use by large scale farmers than small holders is due to the large proportion of uncultivated lands in this system. Feed conservation practices and crop residue utilization are poor in both production systems. The natural pasture provides larger proportion of the feed resource in the wet season, but it hardly satisfies the quantity and quality required by the animal in dry season. Moreover, availability of other feed resources is less [35], indicating the common phenomenon of feed shortage during the dry season. 
Table 7. Sheep feed resources ranked by respondents and priority indices in smallholder and large scale production systems.

\begin{tabular}{ccccccc}
\hline & \multicolumn{2}{c}{ Smallholder } & \multicolumn{2}{c}{ Large scale systems } & \multicolumn{2}{c}{ Overall } \\
\cline { 2 - 7 } & Wet & Dry & Wet & Dry & Wet & Dry \\
\hline Feed source & I & I & I & I & I & I \\
\hline Communal grazing & 0.75 & 0.38 & 0.67 & 0.33 & 0.71 & 0.36 \\
Private grazing & 0.17 & 0.22 & 0.2 & 0.28 & 0.19 & 0.25 \\
Crop residues & 0.05 & 0.11 & 0.00 & 0.12 & 0.03 & 0.11 \\
Trees and shrubs & 0.03 & 0.16 & 0.13 & 0.17 & 0.07 & 0.17 \\
Crop after math & 0.00 & 0.13 & 0.00 & 0.08 & 0.00 & 0.11 \\
\hline
\end{tabular}

$\mathrm{I}=$ index; $\mathrm{I}=$ sum of [ 3 for rank $1+2$ for rank $2+1$ for rank 3 ] given for an individual feed divided by sum of [ 3 for rank $1+2$ for rank $2+1$ for rank 3$]$ summed for all the feeds.

The present study confirmed the finding of the previous studies [10] [22] who noted reduced pasture productivity in time and getting dry and scarce in the dry season. The scarcity of feed is more exacerbated by large number of seasonal transhumant livestock movement from the neighboring districts to the study areas in search of feed during the main rainy season and the poor feed conservation practices in the area [10] [14] [22]. To bridge the dry season feed shortage, a high percentages of both smallholder and large scale farmers' use fed supplements such as crop by products (sesame seed cake and wheat bran) and sorghum grains. Feed supplementation target the critical feed shortage period (March through to May), and mainly offered to sick animals. Improvement of extensive sheep production system through introduction of better feed development and conservation mechanism is very important. Among the various suggested strategies, supplementing the fibrous low quality basal diet with more nutritious and digestible feedstuffs could be one of the solutions to alleviate this situation and to improve sheep productivity. In this regard, [35] noted that sheep offered noug seed cake as supplement to hay showed higher body weight gain performance and conversion efficiency than those consumed only hay. Therefore, interventions that improve the productivity of sheep are important in creating wealth and improving the standard of living of resource-poor farmers [36].

Table 8 presents the percentages of household grazing management and ways of herding across the production systems in the study areas. Sheep production is based on free grazing in the study areas. All of the respondents in the large scale systems reported that sheep flock was herded alone without mixing with other flocks. whereas $42.5 \%$ of the smallholder farmers herding their sheep flocks separately and $55.9 \%$ herding with their neighboring and the rest $1.7 \%$ herding their flocks with Sudan pastoralists in the communal rangelands. There is the possibility of mixing flocks with other neighbouring and transhumance Sudan pastoralist's sheep flocks. In Afar, pastoralist (64.8\%) explained that their animals mix with others flocks during the rainy season [4]. Although, mixing of flocks reported by more than half of the smallholder farmers has importance of using rams in the communal grazing areas and reduces the risk of inbreeding and it 
Table 8. Percent of respondents who used different management type for grazing and herding of sheep across production system in the study areas.

\begin{tabular}{cccc}
\hline Management type & Smallholders $(\mathrm{N}=180)$ & Large Scale $(\mathrm{N}=60)$ & Over all $(\mathrm{N}=240)$ \\
\hline Grazing management & 100 & 100 & 100 \\
Free grazing & & & \\
Way of herding & 42.5 & 100 & 71.3 \\
Herded separately & 55.9 & - & 27.9 \\
Herded with neighbouring flocks & 1.7 & - & 0.8 \\
Herded with pastoralists & &
\end{tabular}

$\mathrm{N}=$ number of obeservation.

might be create uncontrolled mating between the Gumz and Rutana sheep breed.

\section{Sheep health problems}

Disease prevalence are often regarded to be major factors limiting the productivity of sheep raised by most rural farmers in the tropics and sub tropics [20] and the farmers are not able to achieve the expected amount of benefit from sheep production. Foot rot, pasteurellosis and respiratory disease are the major sheep diseases which affect sheep productivity in the smallholder production systems of the present study area and veterinary health care is also poor. Vaccination was provided for few common diseases and the service was provided by the government only during seasonal outbreak. Some smallholder farmers indicated that they sourced help from government veterinary services, while most of them treat the animals themselves by buying drugs from private drug suppliers. Sheep pox, pasteurellosis and external parasites comprise the major reported diseases in the large scale systems. In contrast, employed veterinarians treat the sick animals in most of the large scale farmers. Types of disease and limited veterinary services reported in this study were in agreement with earlier reports [4] [11]. Similarly, these findings agree with previous reports [27] [37] that identified these factors as constraints to sheep production in different parts of the country as well as in the tropics [20]. Thus, previous and current findings indicate that healthcare to be one of the important packages that shall be considered during genetic improvement and designing of conservation programs. Application of train and visit methods of veterinary extension to farmers would result in improved disease diagnosis and ultimately improve animal health husbandry. Wider utilization of indigenous breeds tolerant to disease could be another way in alleviating some of the problems. Farmers should also be made aware that they need to dip and vaccinate their sheep in order to reduce disease incidences. The advantage of using locally adapted breeds as the way of combating diseases hence improving the livelihood of the rural Poor has been discussed elsewhere in tropics [38]. (Table 9)

\subsection{Marketing Systems}

Sale of live animals is the primary purpose of sheep keeping followed by house 
Table 9. Major sheep disease ranked by respondents and priority indices in different production systems.

\begin{tabular}{ccccccccccc}
\hline & \multicolumn{3}{c}{ Smallholders } & \multicolumn{5}{c}{ Large scale } & \multirow{2}{*}{ Over all I } \\
\cline { 2 - 8 } Diseases & 1 & 2 & 3 & I & 1 & 2 & 3 & I & \\
\hline Foot rot & 17.8 & 20.6 & 25.0 & 0.20 & 13.3 & 10.0 & 21.7 & 0.13 & 0.17 \\
Internal parasites & 15.6 & 12.8 & 17.2 & 0.16 & 11.7 & 18.3 & 13.3 & 0.14 & 0.15 \\
ORF & 16.7 & 11.1 & 15.6 & 0.14 & 6.7 & 6.7 & 10.0 & 0.07 & 0.11 \\
Pasteurellosis & 18.3 & 22.8 & 12.8 & 0.19 & 15.0 & 25.0 & 11.7 & 0.18 & 0.19 \\
Sheep pox & 7.8 & 9.4 & 3.9 & 0.08 & 26.7 & 8.3 & 11.7 & 0.18 & 0.13 \\
Respiratory disease & 15.6 & 5.0 & 15.6 & 0.16 & 10.0 & 20.0 & 13.3 & 0.14 & 0.15 \\
External parasites & 8.3 & 5.6 & 10.0 & 0.07 & 16.7 & 11.7 & 18.3 & 0.15 & 0.10 \\
\hline
\end{tabular}

$\mathrm{I}=$ index; $\mathrm{I}=$ sum of [ 3 for rank $1+2$ for rank $2+1$ for rank 3 ] given for an individual disease divided by sum of [ 3 for rank $1+2$ for rank $2+1$ for rank 3 ] summed for all the diseases.

consumption. Sheep were sold throughout the year for export market since there is always demand for sheep in Sudan. Both legal and informal sheep trade are operating at different magnitudes in the Ethio-Sudan cross-border. [10] [39] also reported the existence of trans-boundary trade between Ethiopia and Sudan which operate under legal and informal routs. About $68 \%$ of the large scale farmers primarily target legal traders who supply sheep for export market, while $25 \%$ targeted hired traders. On contrary, 56\% of smallholder farmers target informal hired traders who supply sheep for export market, while $29 \%$ of smallholder target primarily household consumptions. [39] reported that hired traders come from Sudan to north western lowlands and make deal and transfer the animal through illegal routs. The practice of informal trade might be due to the high tariff rate charged in legal trade. Smallholder farmers indicated that higher price is received when they sold for informal traders compared to legal traders. According to interview result, $78.1 \%$ of smallholder farmers offer sheep for sale to meet their urgent needs at any time during the year. This supports the results of other authors who indicated sales of animals in order to meet emergencies of cash need [39]. About $21.9 \%$ of smallholder farmer's sold during major holidays of Christian and Muslims. On contrary, $86 \%$ of the large scale farmers indicated that they supply sheep to export market throughout the year. This is probably due to the perennial demand of sheep and attractive price in Sudan market. While, $14 \%$ of the large scale farmers sold sheep during major holidays of Muslims. This could be an added advantage to implement breed improvement program. Many breeding plan have failed since they do not consider market demand elsewhere in the world.

Animals are sold at an early age and males of $3-6$ months in smallholder (34.2\%) and 6 - 12 months in large scale systems (48.1\%) contributed the highest percentages of sold animals indicating young males are the most demanded and required class by sheep exporters and also fetched higher price as compared to other age group of sheep in Sudan market. However, this practice will have an impact on inbreeding and loss of genetic material since males that are rapidly growing are picked and sold before used for mating. Earlier work also reported 
negative selection practices due to the sale of best performing young animals [4] [7] [40] [41] noted that complete lack or insufficient number of breeding males in sheep flocks result in delayed services and negatively affect the flocks' reproductive performance and overall productivity. Breeding ewes were sold (3.6\%) to local market very rarely in large scale systems than smallholder systems (14.4\%). This may be due to the fact that large scale sheep owners kept females for breeding and only sold aged and un-productive ewes. Most common sheep breed sold to export market throughout the year was the Rutana sheep and its crosses. Rutana and its crosses fetched higher prices than Gumz sheep. The Gumz sheep was more preferable on domestic market and local consumers' prefer Gumz sheep meat than Rutana which show the superiority of one breed over another in terms of growth and carcass characteristics [42] [43] (Table 10).

In both systems, sheep are one of the income sources for farmers which are similar to previous reports [4]. The money obtained from the sale of this animal is used to purchase different utilities (Table 11). This finding agrees with the

Table 10. Traded sheep by age and sex in $2015 / 16$ as reported by respondents.

\begin{tabular}{cccccccc}
\hline Age group & Sex & \multicolumn{2}{c}{ Smallholder $(\mathrm{N}=180)$} & \multicolumn{2}{c}{ Large scale $(\mathrm{N}=60)$} & \multicolumn{2}{c}{ Overall $(\mathrm{N}=240)$} \\
\hline \multirow{2}{*}{$<6$ months } & & $\mathrm{N}$ & $\%$ & $\mathrm{~N}$ & $\%$ & $\mathrm{~N}$ & $\%$ \\
& $\mathrm{M}$ & 38 & 14.5 & 188 & 23.5 & 226 & 21.4 \\
& $\mathrm{~F}$ & 31 & 11.8 & 166 & 20.9 & 197 & 18.6 \\
& $\mathrm{M}-12$ months & 52 & 19.7 & 196 & 24.6 & 248 & 23.4 \\
& $\mathrm{~F}$ & 59 & 22.4 & 155 & 19.5 & 214 & 20.2 \\
$<12$ months & $\mathrm{M}$ & 45 & 17.1 & 61 & 7.7 & 106 & 10.0 \\
& $\mathrm{~F}$ & 38 & 14.4 & 29 & 3.6 & 67 & 6.3 \\
All ages & $\mathrm{M}$ & 135 & 51.3 & 445 & 56.0 & 580 & 54.8 \\
& $\mathrm{~F}$ & 128 & 48.7 & 350 & 44.0 & 478 & 45.2 \\
Overall & & 263 & 100 & 795 & 100 & 1058 & 100 \\
\hline
\end{tabular}

$\mathrm{N}=$ Number of households; $\mathrm{M}=$ Male; $\mathrm{F}=$ Female.

Table 11. Reported reasons for sale of sheep by smallholder respondents.

\begin{tabular}{cccccc}
\hline Smallholder production systems & & & \\
\hline Use of income & 1 & 2 & 3 & Index \\
\hline Buy food & 26.7 & 8.3 & 7.2 & 0.17 \\
Buy seed & 14.4 & 11.1 & 2.8 & 0.11 \\
Buy breeding sheep & 8.3 & 2.8 & 2.8 & 0.05 \\
Buy cloth & 9.4 & 17.8 & 12.8 & 0.14 \\
Pay tax & 11.7 & 19.4 & 6.7 & 0.13 \\
Buy household supplies & 9.4 & 16.4 & 7.2 & 0.11 \\
Buy feed & 7.8 & 7.8 & 10.6 & 0.08 \\
Saving & 0.0 & 1.1 & 9.4 & 0.02 \\
Buy school supplies & 3.9 & 8.9 & 24.4 & 0.09 \\
Vet services & 8.3 & 11 & 16.1 & 0.10 \\
\hline
\end{tabular}

$\mathrm{I}=$ index; $\mathrm{I}=\operatorname{sum}$ of [ 3 for rank $1+2$ for rank $2+1$ for rank 3 ] given for an individual uses divided by sum of [ 3 for rank $1+2$ for rank $2+1$ for rank 3 ] summed for all the uses. 
earlier reports [25] indicating the importance of small ruminants as main source of household income for farmers and pastorals in various developing countries.

\section{Conclusion}

The study revealed a number of relevant issues that help in developing effective breed conservation and improvement programmes of the breed. It identified two sheep production systems (smallholder and large-scale commercial) and two sheep breeds and their crossbreed. The two production systems varied in their sheep production, breeding and marketing strategies. The adapted local genetic resource of Gumz breed which accounted for the wide genetic diversity of sheep resources in Ethiopia and the thin-tailed local breed [12] is losing its genetic diversity and considered to be endangered. It is thus essential to design a conservation based breeding program for the Gumz breed. The design of breeding program needs to consider the sustainable utilization of the purebred Rutana sheep and the crossbreeding component. The program needs to be a comprehensive one involving the two sheep breeds and their crossbred in the area. Hence, we recommend designing of conservation-based breeding program to conserve the locally adapted Gumz breed as well as to improve sheep production and productivity in the area through rational utilization of all the two genotypes and their crossbred. For designing a sustainable breeding program for Gumz sheep, the traditional management system, production objectives, herding and breeding practices, marketing and production constraints specific to the two systems identified in this study shall be considered. Feed resource management interventions, efficient delivery of animal health services and profitable market outlets are required to increase the benefits of sheep rearing to the keepers of these valuable sheep resources.

\section{Acknowledgements}

We would like to thank Gondar Agricultural research center, Development Agents for their support during the field work and making the data available for the study. The financial support of the Ministry of Education and Bule Hora University is also highly acknowledged.

\section{References}

[1] CSA (Central Statistics Agency) (2015) Agricultural Sample Survey 2014/15. Volume II Report on Livestock and Livestock Characteristics (Private Peasant Holdings), Central Statistical Agency (CSA), Addis Ababa, Ethiopia, 188 p.

[2] Markos, T. (2006) Productivity and Health of Indigenous Sheep Breeds and Crossbreds in the Central Ethiopian Highlands. PhD Dissertation, Department of Animal Breeding and Genetics, Faculty of Veterinary Medicine and Animal Sciences, Swedish University of Agricultural Science (SLU), Uppsala, Sweden, 74 p.

[3] Tsegaye, T., Mengistu, U., Yoseph, M. and Merga, B. (2013) Pre-Weaning Growth Performance of Crossbred Lambs (Dorper $\times$ Indigenous Sheep Breeds) under Semi-Intensive Management in Eastern Ethiopia. Tropical Animal Health and Production, 46, 455-460. 
[4] Getachew, T., Haile, A., Tibbo, M., Sharma, A.K., Sölkner, J. and Wurzinger, M. (2010) Her Management and Breeding Practices of Sheep Owners in a Mixed Crop-Livestock and a Pastoral System of Ethiopia. African Journal of Agricultural Research, 5, 685-691.

[5] Hailemariam, F., Melesse, A. and Banerjee, S. (2013) Traditional Sheep Production and Breeding Practice in Gamogofa Zone, Southern Ethiopia. International Journal of Livestock Production Research, 1, 26-43.

[6] Asegede, M., Bisrat, A., Hagos, Y. and Gugsa, G. (2015) Livestock Market Value Chain Assessment in Selected Sites of Tigray, North Ethiopia: Challenges and Opportunities for Enhancing Animal Product Export. Global Veterinaria, 14, 48-55.

[7] Gizaw, S., Haile, A. and Dessie, T. (2010) Breeding Objectives and Breeding Plans for Washera Sheep under Subsistence and Market Oriented Production Systems. Ethiopian Journal of Animal Production, 10, 1-16.

[8] IGAD (2011) The Contribution of Livestock to the Ethiopian Economy-Part II, IGAD Livestock Policy Initiative. Roy Behnke, Odessa Centre, Great Wolford, UK.

[9] Legesse, G., Haile, A., Duncan, A.J., Dessie, T., Gizaw, S. and Rischkowsky, B. (2014) Sheep and Goat Value Chains in Ethiopia: A Synthesis of Opportunities and Constraints. ICARDA/ILRI Project Report, International Center for Agricultural Research in the Dry Areas/International Livestock Research Institute, Nairobi, Kenya.

[10] Mulugeta, E., Gebremedhin, B., Hoekstra, D. and Mohammed, J. (2007) Analysis of the Ethio-Sudan Cross-Border Cattle Trade: IPMS (Improving Productivity and Market Success) of Ethiopian Farmers Project Working Paper 2. ILRI (International Livestock Research Institute), Nairobi, Kenya.

[11] Solomon, A., Hegde, B.P. and Mengistie, T. (2011) Growth and Physical Body Characteristics of Gumuz Sheep under Traditional Management Systems in Amhara Regional State, Ethiopia. Livestock Research for Rural Development, 23, 1-5.

[12] Gizaw, S., Abegaz, S., Rischkowsky, B., Haile, A., Mwai, A.O. and Dessie, T. (2013) Review of Sheep Research and Development Projects in Ethiopia. International Livestock Research Institute (ILRI), Nairobi, Kenya.

[13] FAO (2012) Phenotypic Characterization of Animal Genetic Resources. FAO Animal Production and Health Guidelines No. 11, Rome.

[14] Desalew, T., Tegegne, A., Nigatu, L. and Teka, W. (2010) Rangeland Condition and Feed Resources in Metema District, North Gondar Zone, Amhara Region, Ethiopia. IPMS (Improving Productivity and Market Success) of Ethiopian Farmers Project Working Paper 25, Nairobi, Kenya, ILRI, 74 p.

[15] Tadesse, H. and Afework, B. (2008) Habitat Association of Insectivores and Rodents of Alatish National Park, Northwestern Ethiopia. Tropical Ecology, 49, 1-11.

[16] Freund, R.J. and Wilson, W.J. (2003) Statistical Methods. Academic Press, New York.

[17] Ayalew, W., Vandorland, A. and Rowlands, G.J., Eds. (2004) Designing, Execution and Analysis of the Livestock Breed Survey in Oromia Regional State, Ethiopia, OADB (Oromia Agricultural Development Bureau, Addis Ababa, Ethiopia, and ILRI (International Livestock Research Institute), Nairobi, Kenya, 260 p.

[18] ILCA (1990) ILCA Annual Report 1989: 29-31. ILCA, Addis Ababa.

[19] Kosgey, I.S. (2004) Breeding Objectives and Breeding Strategies for Small Ruminants in the Tropics. PhD Thesis, Wageningen University, The Netherlands, $272 \mathrm{p}$.

[20] Kosgey, I.S., Rowlands, G.J., van Arendonk, J.A.M. and Baker, R.L. (2008) Small ruminant Production in Smallholder and Pastoral/Extensive Farming Systems in 
Kenya. Small Ruminant Research, 77, 11-24.

https://doi.org/10.1016/j.smallrumres.2008.02.005

[21] Mavule, B.S., Muchenje, V. and Kunene, N.W. (2013) Characterization of Zulu Sheep Production System: Implications for Conservation and Improvement, 8, 1226-1238.

[22] Amare, S. (2006) Qualitative and Quantitative Aspects of Animal Feed in Different Agro-Ecological and Agriculture: Livestock in the Balance. FAO, Rome, 14.

[23] Tegegne, F. and Asefa, G. (2010) Feed Resource Assessment in Amhara Regional State. Ethiopian Sanitary and Phytosanitary Standards and Livestock Meat Marketing Program (SPS-LMM), Texas A\&M University System.

[24] Hassen, A.S. and Tesfaye, Y. (2014) Sheep and Goat Production Objectives in Pastoral and Agro-Pastoral Production Systems in Chifra District of Afar, Ethiopia. Tropical Animal Health and Production, 46, 1467-1474. https://doi.org/10.1007/s11250-014-0668-4

[25] Mengistie, T., Girma, A., Solomon, G., Sisay, L., Abebe, M. and Markos, T. (2010) Traditional Management Systems and Linear Body Measurements of Washera Sheep in the Western Highlands of the Amhara National Regional State, Ethiopia. Livestock Research for Rural Development, 22, 1-16.

[26] Wurzinger, M., Ndumu, D., Maumung, R., Drucker, A.G., Okeyo, A.M., Semambo, D.K. and Sölkner, J. (2006) Stated Preferences through Use of Choice Experiments: Valuing (Re)Production versus Aesthetics in the Breeding Goals of Ugandan Ankole Cattle Breeds. Proceedings of the 8 th World Congress on Genetics Applied to Livestock Production, Belo Horizonte, Brazil, 13-18 August 2006, 1-4.

[27] Nigussie, H., Mekasha, Y., Kebede, K., Abegaz, S. and Pal, S.K. (2015) Indigenous Sheep Production System in Eastern Ethiopia: Implications for Genetic Improvement and Sustainable Use. American Scientific Research Journal for Engineering, Technology, and Sciences (ASRJETS), 11, 136-152.

[28] Edea, Z., Haile, A., Tibbo, M., Sharma, A.K., Sölkner, J. and Wurzinger, M. (2012) Sheep Production Systems and Breeding Practices of Smallholders in Western and South-Western Ethiopia: Implications for Designing Community-Based Breeding Strategies. Livestock Research for Rural Development, 24, 7.

[29] Mekoya, A., Yami, A. and Hailemariam, M. (2000) Management of Traditional Sheep Production in Lallomamma Mider District. North Shoa, Amhara, 143-153.

[30] Fekerte, F. (2008) On-Farm Characterization of Blackhead Somali Sheep Breed and Its Production System in Shinile and Erer Districts of Shinile Zone. MSc Thesis, School of Graduate Studies of Haramaya University of Agriculture, Dire Dawa, Ethiopia, $115 \mathrm{p}$.

[31] Gizaw, S., van Arendonk, J.A.M., Valle-Zárate, A., Haile, A., Rischkowsky, B., Dessie, T. and Mwai, A.O. (2014) Breeding Programmes for Smallholder Sheep Farming Systems: II. Optimization of Cooperative Village Breeding Schemes. Journal of Animal Breeding and Genetics, 131, 350-357. https://doi.org/10.1111/jbg.12102

[32] Seare, T., Gangwar, S.K. and Kebede, K. (2011) Performance and Physical Body Measurement of Abergell Sheep Breed under Traditional Management System of Tigray Regional State, Northern Ethiopia. International Journal of Science and Nature, 2, 225-230.

[33] Mapiliyao, L. (2010) Sheep Production Practices, Flock Dynamics, Body Condition and Weight Variation in Two Ecologically Different Resource Poor Communal Farming Systems. MSc Thesis, University of Fort Hare, South Africa, 136 p.

[34] Kynock, G. and Ulicki, T. (2001) Cross-Border Raiding and Community Conflict in 
the Lesotho South African Border Zone. Southern African Migration Project (SAMP), Migration Policy Series No. 21.

[35] Beshaw, S. and Melaku, S. (2008) Bodyweight and Carcass Characteristics of Somali Goats Fed Hay Supplemented with Graded Levels of Peanut Cake and Wheat Bran Mixture. Tropical Animal Health and Production, 40, 553-560. https://doi.org/10.1007/s11250-008-9133-6

[36] Hirpa, A. and Abebe, G. (2008) Economic Significance of Sheep and Goats. Sheep and Goat Production Handbook for Ethiopia, Branna Printing Enterprise, Addis Ababa, 2-24.

[37] Hassen, A., Ebro, A., Kurtu, M. and Treydte, A.C. (2010) Livestock Feed Resources Utilization and Management as Influenced by Altitude in the Central Highlands of Ethiopia. Livestock Research for Rural Development, 22, 229-233.

[38] Devendra, C. (2001) Small Ruminants: Imperatives for Productivity Enhancement Improved Livelihoods and Rural Growth-A Review. Asian-Australian Journal of Animal Sciences, 14, 1483-1496. https://doi.org/10.5713/ajas.2001.1483

[39] Tesfay, Z., Anal, A.K. and Gebreyohanis, G. (2012) Assessment of the Sheep Production System of Northern Ethiopia in Relation to Sustainable Productivity and Sheep Meat Quality. International Journal of Advanced Biological Research, 2, 302313.

[40] Seleka, T.B. (2001) Determinants of Short-Run Supply of Small Ruminants in Botswana. Small Ruminant Research, 40, 203-214. https://doi.org/10.1016/S0921-4488(01)00182-1

[41] Mirkena, T., Duguma, G., Haile, A., Tibbo, M., Okeyo, A.M., Wurzinger, M. and Solkner, J. (2010) Genetics of Adaptation in Domestic Farm Animals: A Review. Livestock Science, 132, 1-12. https://doi.org/10.1016/j.livsci.2010.05.003

[42] Dossa, L.H., Sangare, M., Buerkert, A. and Schlecht, E. (2015) Production Objectives and Breeding Practices of Urban Goat and Sheep Keepers in West Africa: Regional Analysis and Implications for the Development of Supportive Breeding Programs. SpringerPlus, 4, 281-290. https://doi.org/10.1186/s40064-015-1075-7

[43] Macfarlane, J.M. and Simm, G. (2007) The Contribution of Genetic Improvement for Lamb Meat Production. Paper presented at 3rd International Symposium about Goat and Sheep Meat Type, 3rd Sincorte, João Pessoa, Paraiba, Brazil.

\section{Scientific Research Publishing}

\section{Submit or recommend next manuscript to SCIRP and we will provide best service for you:}

Accepting pre-submission inquiries through Email, Facebook, LinkedIn, Twitter, etc. A wide selection of journals (inclusive of 9 subjects, more than 200 journals)

Providing 24-hour high-quality service

User-friendly online submission system

Fair and swift peer-review system

Efficient typesetting and proofreading procedure

Display of the result of downloads and visits, as well as the number of cited articles

Maximum dissemination of your research work

Submit your manuscript at: http://papersubmission.scirp.org/

Or contact ojas@scirp.org 